\title{
Ethical and Political Implications of "Performance" in a Rural Cultural Practice: Afro-Colombian Women Singers from the Town of Pogue*
}

\author{
Paola Marín ${ }^{1}$ [D, Gastón Alzate ${ }^{1}$ (])
}

This essay relates to a broader investigation on art and social change in Colombia to be published in the book Performances that Changed the Americas, edited by Stuart Day (forthcoming 2021)

'Professor, Department of Modern Languages and Literatures, California State University-Los Angeles, Los Angeles, USA

ORCID: P.M. 0000-0003-0321-4517;

G.A. 0000-0002-2474-7980

Corresponding author / Sorumlu yazar: Gastón Alzate,

Professor, Department of Modern Languages and Literatures, California State University-LoS Angeles, Los Angeles, USA

E-mail/E-posta: galzate@calstatela.edu

Submitted/Başvuru: 09.03.2021

Revision Requested/Revizyon Talebi: 27.04.2021

Last Revision Received/Son Revizyon: 27.04.2021

Accepted/Kabul: 05.05.2021

\section{Citation/Atıf:}

Marín, Paola, Alzate, Gastón. "Ethical and politica Implications of "performance" in a rural cultural practice: Afro-colombian women singers from the town of Pogue". Tiyatro Eleștirmenliğive Dramaturji Bölümü Dergisi 32, (2021): 1-22. https://doi.org/10.26650/jtcd.890946

\section{ABSTRACT}

This article analyzes a group of Afro-Colombian female singers from Pogue, a rural area of the Colombian Pacific who have reinvented traditional mourning songs (alabaos). Their music and performance refer to the massacres and abuses committed by both the FARC leftist guerrilla group and the rightwing paramilitary in the nearby village of Bojayá. We will not study these traditional mourning songs from an ethnographic perspective, but from the interdisciplinary perspective of performance studies. As such, the aim here is to emphasize the wider political and artistic dimension of the songs vis-àvis Colombian necropolitics. However, we will still rely on the work of social scientists as we recognize the importance of grounding our analysis on a specific reality. In addition, we find a foothold on Rustom Bharucha's perspective on the performativity of "terror' in the Global South, as we think this Indian cultural critic is spot-on when questioning the "war on terror" master narrative resulting from the attacks on September 11, 2001, and looking instead at other areas of the world where "terror" assumes a concrete and visceral dimension in everyday life.. Keywords: Cultural Performance, Theater and Performance, Necropolitics, Colombian Peace Process, The Pogue Singers 


\section{Introduction}

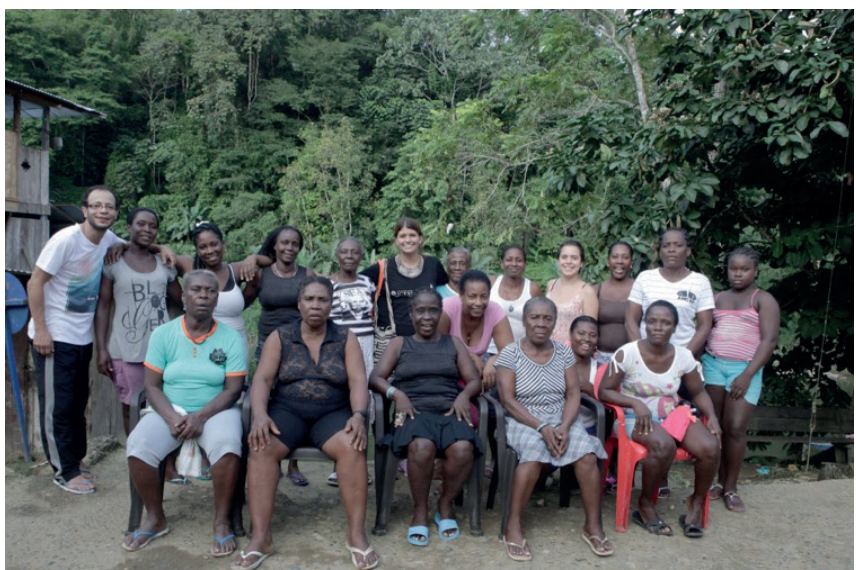

Some members of the Pogue Singers with the director of the documentary Voces de Resistencia $\left(\mathrm{ICESI}^{1}\right)$

In this article we are interested in analyzing a Latin American rural practice that emerged from the traditional culture of a marginalized area of Colombia where the majority of inhabitants are Afro-descendant. The Pogue singers gained public recognition for their specific connection to the 2016 peace process that sought to end the 50-year violent conflict in Colombia. We are convinced that social change is not possible without appropriating the past, no matter how horrific, and more so when in Colombia violence in rural areas since 2016 has decreased but has not stopped, despite the fact that this so called "process" allowed Juan Manuel Santos (President of Colombia from 2010 to 2018) to win the Nobel Peace Prize in 2016. We will base our investigation on the Indian cultural critic Rustom Bharucha's perspective on the performativity of "terror" in the Global South, as we believe that Barucha is right in challenging the master narrative of the "war on terror" resulting from the attacks of September 11, 2001, and looking instead at other zones of the world where "terror" adopts a tangible and visceral dimension in ordinary life:

In this scenario, which is more truly global than the essentially American war on terror, there needs to be some way of calling attention to these other manifestations of terror, which are not determined by 'September 11', even though they may be affected by its fall-out. Far from being exceptional, terror can be regarded as the new banality of evil in our times, functioning in a diversity of ways, open to a spectrum of causes, manipulations, rumours, fears, tensions, and resentments, ranging from the most global and national of political interventions to the most quotidian intimacies of everyday life. ${ }^{2}$

1 All images of Pogue's singers in this essay belong to the CEAF (Centro de Estudios Afrodiaspóricos- Center for Afrodiasporic Studies), ICESI University (Cali - Colombia).

2 Rustom Bharucha, Performance and Terror (New York: Routledge, 2014). 
The relationship between alabaos (mourning songs) and terror that we establish in this article is related to the killings and disappearance of civilians at the hands of the armed actors of the Colombian conflict -including the State- over the late $20^{\text {th }}$ and early $21^{\text {st }}$ centuries in the area where the village of Pogue is located. While the music of these traditional chants and the way in which they are performed have remained the same, their centuries-old style of lyrics has been modified by the town inhabitants due to the extreme violence affecting their community. In keeping with Bharucha's statement, on one hand alabaos show both how violence impacts daily life and how this change is related to the overall political situation of Colombia, and as such, to global political interests.

As is well recognized, Richard Schechner described performance in terms of restoration of behavior, that is, as "twice-behaved behavior". ${ }^{3}$ However, we think that theories must be transformed and examined against particular settings and milieus, predominantly in the case of territories such as Colombia, outside the Western cultural context where the interdisciplinary field of performance studies has developed. Therefore, while we are aware of the relevance of Schechner's statement, we believe that it is crucial to identify its problematic ethical and political implications. Regarding this issue, Bharucha writes: "Arguably, contexts of terror and genocide decimate the very idea of 'restoration' in the first place, compelling one to consider 'how'new concepts and practices are born of the debris of massacres and the annihilation of normative structures and behavior". ${ }^{4}$

On September 26, 2016, the Colombian government put its signature on a peace agreement with the oldest and most dominant leftist guerrilla group in the nation, and probably in Latin America, the Revolutionary Armed Forces of Colombia (FARC). A month later, in October of the same year, contrary to all expectations, 50.2 percent of the Colombian population voted against the agreements with the guerrillas. The results of this referendum to ratify the peace process demonstrated the polarization within Colombian society. This was an unprecedented historical event when compared to similar peace processes such as those in Northern Ireland and South Africa. In this complex and polarized context, we wanted to consider for our analysis a progressive cultural practice that addresses the memory of the Colombian conflict and its aftermath from a primarily female perspective. Instead of approaching our analysis from the conventional angle of political art in which "the political" is understood as an adjective of "art" (which in artistic practice allows performers to stay away from facts), we will inquire how Colombian necropolitics, understood as the use of bodies to exercise power, "activates the creative dimension of political practice". ${ }^{5}$ We will analyze this concept of necropolitics later. For now, let us say that we believe that the subject studied in our article embodies a need

3 Richard Schechner, Performance Studies: An Introduction (New York: Routledge, 2002).

4 Bharucha, Performance and Terror, 133.

5 Ana Longoni, "Perder la forma humana", in Cartografias críticas I, Eds. Ileana Diéguez, Paola Marín, and Gastón Alzate (Los Angeles: Karpa, 2018). 
for new forms of artistic manifestation due to the urgency of the country's historical situation: art, performativity, and politics are intertwined in this creative practice to the point that they cannot be disconnected.

As mentioned above, this essay is not intended as an ethnographic study of alabaos. ${ }^{6}$ Our analysis will be limited to the lyrics and cultural performance of the Pogue singers and to their dialogue with contemporary Colombian political reality. In this sense, we understand cultural analysis as part of the displacement of knowledge that the study of culture, formerly a privileged object of anthropology, has undergone. Therefore, this essay assumes that the reader is familiar with the crisis of dominant epistemological and disciplinary categories taking place over the last decades of the past century in the Humanities. This questioning raised the urgency of opening the limits of ethnography and contributed to breaking the disciplinary limits that made "culture" the sole domain of anthropology and ethnography, and "art" the sole domain of a supposedly universal experience based upon a Western paradigm.

We would also like to make clear that this research does not intend to legitimize per se a particular cultural manifestation. In this sense we want to detach ourselves from a common characteristic of academic studies in the Humanities on activism in Latin America based on the idealization of its political achievements. We sincerely think that this is generally due to the impact of American and European left-wing academia, which, while largely atheistic, frequently privileges and emphasizes the achievement of justice by subaltern subjects or cultures, such as Latin America, without questioning to what extent that vision erases (obscures) experiences other than the optimistic teleology that dominates the political and cultural paradigm of universities and research institutions in the United States and Europe. This phenomenon of academic research appears many times to the disadvantage of the most problematic and intricate facets of activism that occur in the heart of realities that, far from being able to reach an ideal resolution, have implicated and continue to implicate even today the annihilation and disappearance of human beings, as is the case with contemporary Colombia. A good example of what we are trying to explain is the predisposition to assign all the inequalities in the south of the American continent to US imperialism, which, it is worth saying, seems to be a kind of nostalgic holdover from the paradigms of the left in fashion during the Cold War. On the contrary, and thinking about the present economic and political state of affairs in countries such as Nicaragua, Venezuela or Cuba, there is no doubt that such vulgarization of the causes of the catastrophic reality of those countries is not only childlike, but also cynical.

Obviously, we do not attempt to deny the noticeable abuses and inequities in the United States' economic, political, and cultural interactions with Latin America, nor do we attempt to

6 For a fully ethnographic approach to this topic, see: Natalia Quiceno, María Ochoa Sierra and Adriana Marcela Villamizar, «La política del canto y el poder de las alabaoras de Pogue (Bojayá, Chocó)», Estudios Políticos 51 (2017), 175-195. 
negate how the escalation of warmongering narratives is in great part a product of its geopolitics. However, as we will see in our analysis, we must bear in mind that the main perpetrators, facilitators and agents of violence are in our own Latin American countries. Consequently, taking into account cultural and artistic practices within their particular contexts of necropolitics, that is, considering the use and abuse of injured bodies to exercise power, as defined by the Cameroonian academic Achille Mbembe, is vital to escape impulsive triumphalism and indifference regarding the current situation in Colombia. ${ }^{7}$
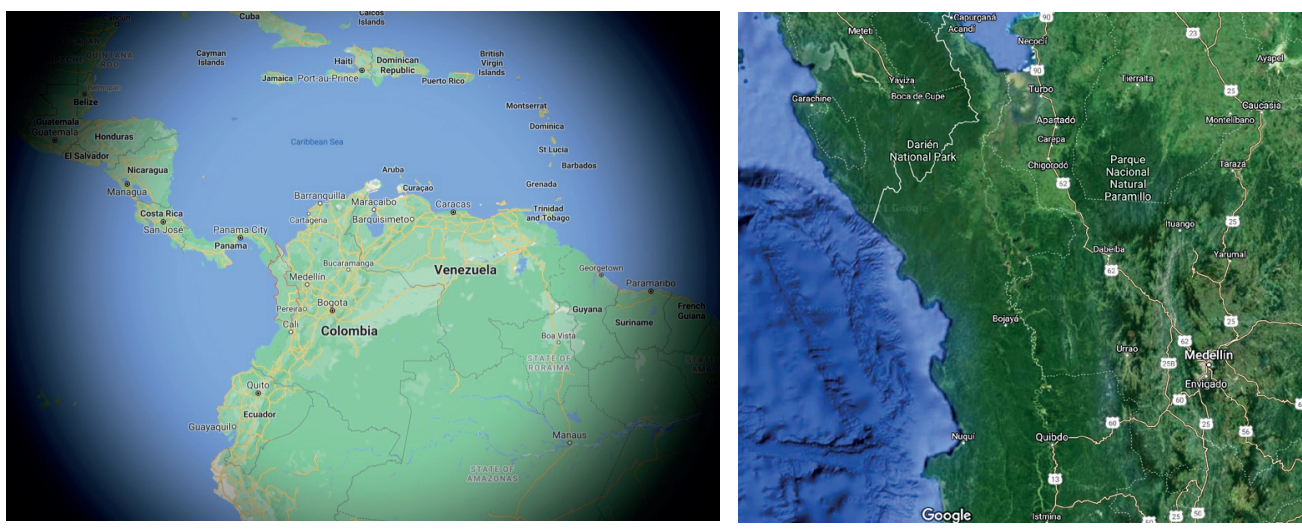

The Department of Chocó in Northwest Colombia borders Panamá. (Google Map)

As discussed by numerous Colombian scholars, including many of the so-called violentologists, ${ }^{8}$ the hegemonic narratives of war delivered by public discourse in the national and international media, most of the national and international government agencies, and the way in which Colombian history is explained at institutional level have together simplified or silenced the origins and consequences of violence for fifty years in thousands of civilian bodies outside the major Colombian capitals. The cultural producers studied in this essay show the need to question these narratives, and despite accepting that a peace process was the best option for their communities and for the country as a whole, their creative practice demonstrates that the public mourning process, while only just beginning, is still weak and full of conflict.

7 Achille Mbembe, Necropolitics (Durham, NC: Duke University Press, 2019).

8 Political violence in Colombia, which has acutely affected the country since 1948 (due to the assassination of the Liberal leader Jorge Eliécer Gaitán), had a very important moment in 1986 when the government of President Virgilio Barco hired a group of scholars from the National University to carry out a study on its causes. This group, led by Professor Gonzalo Sánchez, is known as that of violentologists and their report was published as Pasado y presente en la violencia en Colombia (Past and present of violence in Colombia), edited by Gonzalo Sánchez (1986). For these scientists, violence had objective causes, such as social exclusion and lack of political participation. It is the reason they were interested in finding the origins of daily-life violence in Colombia as a result of organized violence. Later studies contradicted this, arguing that violence has been determined more than anything by the weakness of the institutions. Currently, research tends to show that it is due to a complex combination of economic inequality, institutional causes, and culture. 
For centuries in Colombia, Afro-descendant and indigenous communities have been neglected and abused in what could undoubtedly be called institutional racism. Such is the case in the department of Chocó, particularly in the Bojayá area along the Atrato River, in the Northwest of Colombia, bordering Panama (see maps). Basic services, schooling, health, and other assistance provided by the state are unpredictable or nonexistent in Colombian provinces with isolated Afro-descendant populations.

Along with indigenous communities, Afro-descendants are the population that has suffered the most forced displacement, massacres and human rights abuses in the conflict between armed guerrilla groups, the Colombian police, the military and right-wing paramilitaries, who are known in Colombia as the paras. The latter are armed groups sponsored by wealthy landowners and drug traffickers who often work in coordination with the state armed forces and very dark sectors of the Colombian elites (political parties, members of the industry and some multinational companies $\left.{ }^{9}\right)$. This has occurred from the late 20 th and early 21 st centuries to the present day.

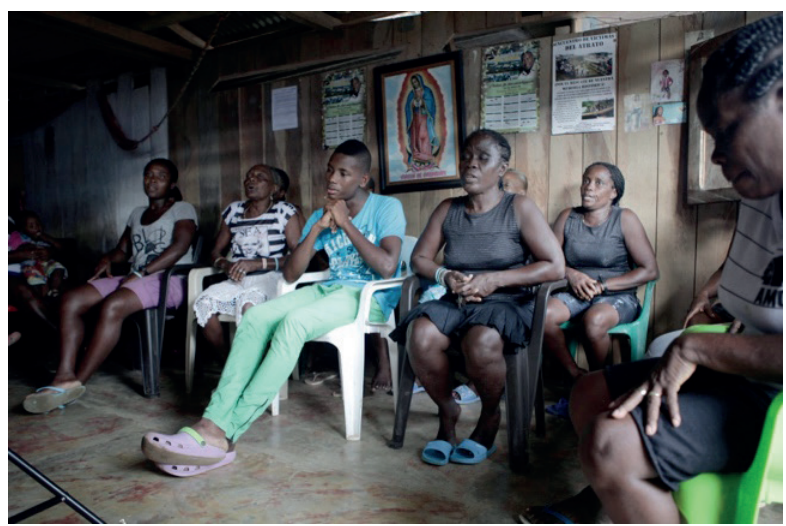

Members of the Pogue Singers at the house of one of them. The house is a small wooden shack. (ICESI)

Faced with the growing violence against the civilian population in their region described above, the Pogue singers began to modify ancestral creative dynamics to compose new lyrics for mourning songs dating from the time of slavery and decided to form a musical group. As Jerónimo Botero and Aurora Vergara have pointed out in "Cantando el territorio" (Singing the

9 Banana businessmen in the regions of Uraba (in the departments of Antioquia and Magdalena in Northwestern Colombia, have been accused of financing paramilitary groups. The Colombian justice system has issued more than 13,000 investigation orders against alleged paramilitary collaborators. This adds to the list of more than 120 entrepreneurs and companies that have been mentioned in the judgments, among which is the well-known multinational Chiquita Brands International, an American producer and distributor of bananas and other products in the world. 
territory), ${ }^{10}$ these changes in the traditional lyrics, as well as the group's transformation into a formal organization, took place in response to the murders and disappearances of civilians occurring in this marginalized area of Colombia since the late 1990s. It was also a consequence of the arrival of right-wing paramilitary forces to a territory where leftist guerrillas were already present and, a direct consequence of the massacre of May 2, 2002, in the neighboring town of Bellavista, in the Bojayá area, where relatives of the singers were assassinated. According to Botero and Vergara, the Pogue singers decided upon a particular performance of public memory that dealt not only with mourning itself but also with denunciation and resistance. As a result, in September 2016 they were invited to sing at the signing ceremony of the peace agreement between the Colombian government and the FARC.

One of the foundations of this article is that performance is a more appropriate category through which to discuss political activism than formal theatrical disciplines based on aesthetic strategies. We believe that this type of approach will help us to ask ourselves about the dominant hierarchical division between "traditional" or "ethnic" cultural acts and the so-called "high" artistic practices, since we are dealing with the cultural production of a group of traditional Afro-descendant Colombian singers. Thus, while we recognize the value and importance of ethnography, here we are not aiming to write an anthropological study.

As initiated by Richard Schechner and Victor Turner, performance studies originated from the need to question Western hierarchies, which for the most part govern the narrow division between (Western) theater and other performing arts, and also to analyze performative social practices, rituals and traditions from the perspective of theater. In the same vein, for this interdisciplinary field the division of the arts by medium is arbitrary. Moreover, in performance studies the object of study is not as clearly defined as are the subjects at the heart of the discipline. Schechner defines performance as "presence, vivacity, agency, incarnation and event". ${ }^{11}$ It is crucial to note here that this kind of approach to popular cultural practices from a performance studies perspective would be artificial if it did not have a foothold in the work of social scientists. Performance studies give a more specific focus on questions such as those mentioned above (for example, on corporality, affect and kinetics), although to arrive at an authentic result it is vital to involve our analysis as much as possible with specific realities, as the Indian critic Bharucha reminds us. ${ }^{12}$ For our study of the Pogue singers, we will center primarily on the Official Report of the Historical Memory Group 2010 on the Bojayá massacre, ${ }^{13}$ whose group is part of the National Commission for Reparation and Reconciliation, and also on the analysis work carried out by Colombian academics Aurora Vergara, a sociologist, and Jerónimo Botero, a political philosopher.

10 Jerónimo Botero and Aurora Vergara. "Cantando el territorio" (paper presented at the annual meeting for the Latin American Studies Association Congress, Barcelona, May 23, 2018).

11 Kirshenblatt-Gimblett cited in Schechner, Performance Studies: An Introduction, 3.

12 See Bharucha, Performance and Terror.

13 Gonzalo Sánchez(coord.) et al, Bojayá: la guerra sin límites: Historical Memory Group Report on Bojayá (Bogotá: CNRR_Grupo de Memoria Histórica, 2010). 


\section{The Pogue Singers: Longing for Peace}

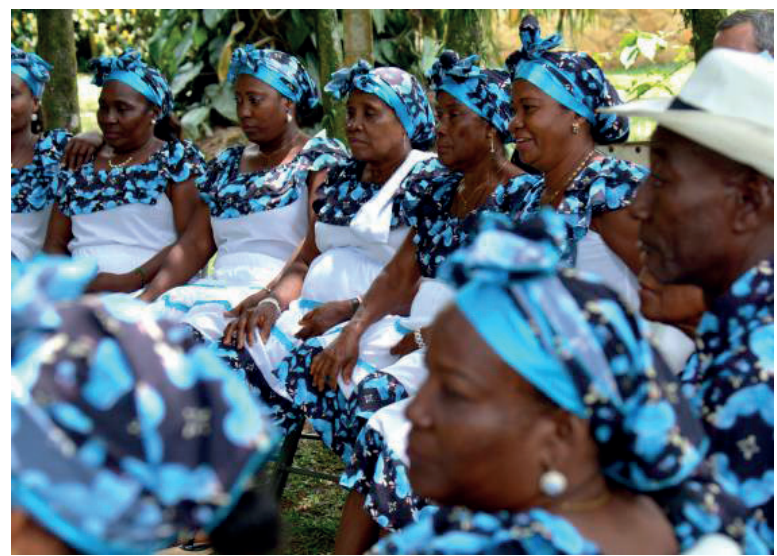

The Pogue Singers performing in traditional Afro-Colombian attire in Bellavista, the site of the massacre (ICESI).

The first thing to say before starting any study on this region is that, like the people of many isolated towns in the country, the inhabitants of Bellavista, Bojayá, had already been abandoned by the state long before the massacre of May 2, 2002. It is known that in 2000, the FARC had deployed in the area due to the growing presence of a paramilitary group. For this reason, the Colombian police, until that moment the only government presence there, withdrew completely, leaving the area at the mercy of illegal gangs (guerrillas from the extreme left and paramilitaries from the extreme right).

Although it is possible to affirm that in Colombia all the armed actors (guerrillas, police/ army and paramilitaries) murdered civilians and brought about their disappearance, thus flagrantly violating human rights, we must make a distinction here. If we are going to speak from the framework of necropolitics, paramilitary tactics were most related to this concept. The objective of the paras has very often not been territorial control but depopulation, which has forced peasants to flee from their place of origin. In this way, they terrorize the rural civilian population through mass murder, gruesome public executions, public gang rape and collective mutilations, which inevitably drive thousands of peasants to flee to urban centers without any means to support themselves. Paramilitaries have also specialized in assassinating leftist social activists, journalists and politicians in urban centers. It is the reason why many villagers, including those belonging to the indigenous Emberá tribe resident on the outskirts of the city, had already run away from the area by the time of massacre. As is customary in Colombia, the government received several notifications of the imminent armed confrontation in its region between these two groups. Among many notifications, there is evidence that the United Nations High Commissioner for Human Rights sent a communication to the Colombian 
government in this regard, as did the Diocese of Quibdó and the Ombudsman's Office, but no protection was provided nor was there any response to these notifications. Due to this, we can affirm that the prevailing necropolitics in Colombia was not only exercised by a parastatal armed group (the paramilitaries) and its adversary (the FARC), but also by the deliberate indifference of the Colombian State.

Through the concept of "homo sacer," Italian thinker Giorgio Agamben explores an idea that may shed light on our study. ${ }^{14}$ Agamben terms homo sacer those who are stripped of their status as citizens and are themselves in a "state of exception" from power. They are excluded from the legal system and, therefore, from the right to life according to Western politics. In this way, necropolitics and biopolitics are related. According to Agamben, who traces this phenomenon back to Aristotle, this situation could be revealed in our days in the laws towards immigrants in today's Europe. In the case of Pogue and the Bojayá area, it is the government's apathy and indolence that displays the ties between the necropolitical and the biopolitical. In Colombia, this dispossession of the human condition of the inhabitants of rural areas carried out by the state - which is thus reduced to what Agamben calls "nuda" (bare) life - does not even require the sanction of bureaucratic processes. In practice, it is based on systemic racism and discrimination towards Afro-descendant, indigenous and peasant communities, as well as towards the inhabitants of the marginal neighborhoods of the cities. ${ }^{15}$

When the battle between the FARC and the paramilitaries broke out on May 2, 2002 many civilians in the town of Bellavista took refuge from the crossfire in the town's church, a space seen as sacred and much better built than their own houses. When the FARC, trying to reach a paramilitary target, threw a gas canister full of shrapnel at the church, the explosion killed more than 90 people including more than 40 children. Others, who took refuge in the church were mutilated or seriously wounded. In this way the place of worship became a macabre scene in which there was human blood and body parts scattered everywhere. ${ }^{16}$ Due to the intensity of the crossfire between the guerrillas and the paramilitaries no one except Minelia, the "madwoman" of the town, assisted the survivors. On her own initiative she moved them to a roofed area and provided them with salted water to stop their bleeding. After four days of battle and in great danger, some twelve villagers buried what was left of their dead in a common grave with just one prayer and without the traditional nine-day funeral rites. Relatives of the victims had to wait more than fifteen years to be able to claim the remains of their loved ones. The Colombian state not only abandoned the population before the attack, but also neglected the survivors

14 Giorgio Agamben, Homo Sacer: El poder soberano y la nuda vida (Valencia: Pre-textos, 1998).

15 A clear example is the case of the "false positives" during the government of Álvaro Uribe from 2002 to 2010 (political advisor to the current Colombian president Iván Duque, 2018-2022), when young people with limited resources attracted by false promises of work, were assassinated by the military and presented as guerrillas killed in combat by the "glorious" national army.

16 Sánchez(coord.) et al, Bojayá: la guerra sin límites: Historical Memory Group Report on Bojayá. 
afterward. The process of identification of remains was not officially "completed" until 2019, and even then, the fragments of twenty people, including those of a child between four and eight years of age, could not be identified. No additional detail is necessary to communicate the sheer brutality and mercilessness of these events.

\section{Alabaos (praises)}

In the Colombian Pacific region, alabaos are responsive a cappella chants performed mainly by women from Afro-descendant communities, although men also join. They are generally given on the eve of a burial, after nine days of funeral rites. It is also possible to hear alabaos sung during Holy Week and during the town's patron saint festivities. The so-called alabaos mayores are about the Virgin Mary, Jesus, God and the saints. Those called alabaos menores refer to the deceased. According to historians, the alabaos emerged sometime in the 17 th century when African slaves, brought in mainly to exploit the mines of the region by European companies, took musical and metric patterns from Spanish prayer songs, gave them new content, combined them with African tonal variations, and established through them a direct supernatural lineage between themselves and the Catholic saints. This cultural practice, according to historian Adriana Maya, allowed Black communities to reestablish the sense of family identity that had been shattered by slavery and helped to rehumanize these communities in the face of terrible working conditions. ${ }^{17}$ In this way we can say that singing alabaos is a practice which revives hope, strengthens collective identity and supports cultural dignity. The alabao culture has been transmitted orally over many generations from parents and grandparents to their children making explicit the reality of the spiritual world to the community; there are those who maintain that "the spirits are the ones that provide melodies to the singers". ${ }^{18}$ In the pamphlet that accompanies a compilation CD of alabaos from the Atrato River area, Gonzalo de la Torre explains that to be an interpreter of alabaos requires a unique talent and that it is a vocation deeply appreciated (De la Torre). This conception of spirituality that connects the past and the present through singing is crucial to understanding the high status of the Pogue singers in the community, as well as the importance of the Catholic denomination to support social cohesion in the Atrato area. Over many centuries the Roman Catholic Church over many centuries officially engaged in a systematic stigmatization of the practices of subjugated natives and enslaved newcomers, yet such communities maintained their cultures through individual and collective acts of resistance. Besides, it must be considered that "knowledge based on a Catholic worldview could also become a local know-how, thus acting as foundation for authentic ways of being and cultural values of their own". ${ }^{19}$

17 Adriana Maya, “Africa: Legados espirituales en La Nueva Granada, siglo XVII”, Historia Crítica 12/1 (1996).

18 Nelly Valencia Cáizamo, "Alabaos y chigualos-gualíes del Chocó traídos al escenario recitalístico del cantante lírico." (MA diss., EAFIT University, 2015), 13.

19 Ana Arango-Melo, Velo que bonito: Prácticas y saberes sonoro-corporales de la primera infancia en la población afro-chocoana (Bogotá D.C.: Opciones Gráficas Editores, 2014), 40. 
After a process of profound changes initiated by Pope John XXIII, alabaos were finally accepted in Catholic celebrations in the second half of the 20th century. This was a change influenced by the Second Vatican Council and the subsequent emergence of liberation theology (synthesis of Christian theology and socioeconomic analysis) adopted by many Colombian priests who had been working with marginalized communities since the $1960 \mathrm{~s} .{ }^{20}$ As a consequence of the above, the Diocese of Quibdó, the capital of the department of Chocó, has deliberately incorporated ethnic practices as part of its social ministry in the region. In municipalities like Bellavista, in the midst of the abandonment of the State and the constant intimidation by armed groups, the priest of the town, Father Antún Ramos, has been one of the few institutional figures who provided support to the community. Father Antún approved the inclusion of rituals of African origin in ceremonies celebrated under his coordination.

Official Catholicism has not been an exception within the Colombian elites in terms of producing injustices, however, it is important to distinguish in this study that there have been important exceptions among members of the clergy who work in marginalized communities. Talking about this kind of solidarity, one of the Pogue's singers, Eugenia Palacios Palacios, composed an alabao in honor of Father Jorge Luis Mazo. Father Mazo was murdered by the paras in a boat on November 17, 1999 for his work with the communities in the Atrato River area.

He was humanitarian in the river of Bojayá
And with all his patience
he was going to visit us /...
The panga that killed him
Belonged to the paramilitaries
He received a heavy blow
That threw him into the Atrato River...
Goodbye, Father Jorge Luis /
You left for no more /
The Pogue community /
Will always remember you. ${ }^{21}$

Since massacres annihilate "normative structures and behavior", ${ }^{22}$ forms of social cohesion such as alabaos are challenged and even broken, and new forms of expressing pain, anger, and memory in the public sphere are born. Consider, for example, a situation in which the practice of singing alabaos as part of the traditional rites for burials that could not take place. In fact, Afro-descendants in the area believe that if the proper rites are not performed with

20 Valencia Cáizamo, "Alabaos y chigualos-gualíes del Chocó traídos al escenario recitalístico del cantante lírico.", 13.

21 Aurora Vergara, "Suffering While Black: Resistance amid Deracination.", in Afrodescendant Resistance to Deracination in Colombia (London: Palgrave McMillan, 2018), 73.

22 Bharucha, Performance and Terror, 13. 
singing, the souls of the dead will not be able to cross over to the afterlife, thus completely altering the social order and community life. As Father Antún said in November 2019: "If the deceased rests, the living can also rest". ${ }^{23}$

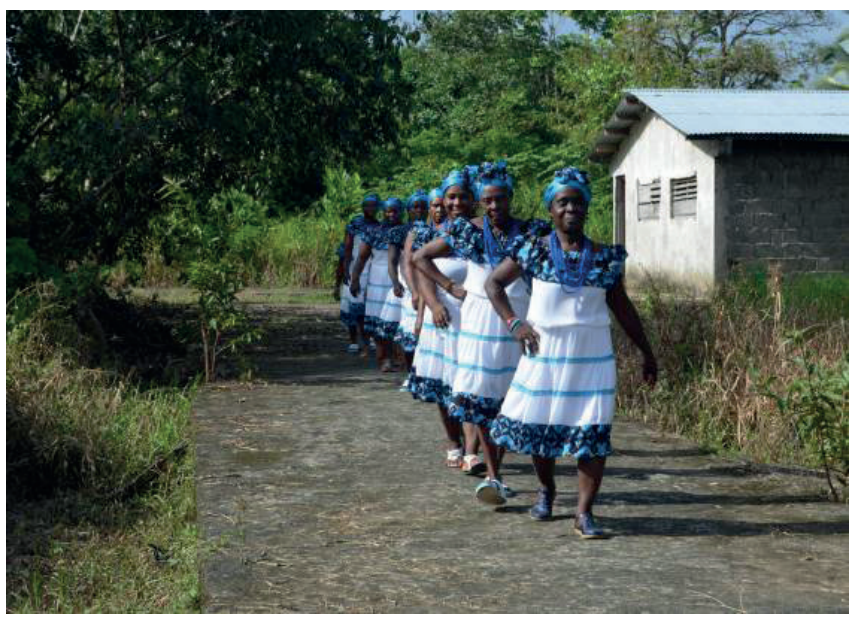

Members of the Pogue singers in Afro-Colombian traditional attire. (ICESI)

The new alabaos by Pogue's singers are quite significant if we take into account that "the Bojayá massacre was not the end of the war on the Atrato River, but the beginning of a new stage of military growth operations," according to the Report of the Historical Memory Group. ${ }^{24}$ Consequently, this endless tragedy increased the risks of damage and forced displacement of the civilian population. In this regard, Botero and Vergara consider that through their music, the Pogue singers 'sing their territory, 'inhabit it with their songs' and (re-appropriate it symbolically)" ${ }^{25}$

Other inhabitants of the region, besides the Pogue singers, have also created rap songs, poems, and even alabaos, and have also organized dance groups related to their own experience of the massacre. ${ }^{26}$ The vast majority of these works are part of traditional oral culture. The lack of a consistent documentation endeavor by the state makes it problematic for these artists to be recognized outside their region. Colombian universities in alliance with institutions in the United States and Europe have sponsored digital and media records, but such efforts are sporadic. A valuable example is Voces de resistencia, about the Pogue singers, a project of the Afro-diasporic Studies Center at ICESI University directed by Aurora Vergara, from which

23 Uno a Uno: Bojayá - memoria atrasada, Diocese of Quibdó and PAZIPAZ, producers 019. www.youtube.com/ watch?v=KmzOJ1y-S4g.

24 Sánchez (coord.) et al, Bojayá: la guerra sin límites: Historical Memory Group Report on Bojayá, 81.

25 Ibid., 11 .

26 Ibid. 
the graphic material of this essay comes. These scholars have carefully studied how Pogue's singers have changed the lyrics of the alabao in accordance with the development of the war in their community. It is important to note that these new alabaos, despite having their origin in the cultural theatrical representations of Catholic pain and mourning, are not ideological, nor do they seek to promote any religious objective or to have a political position. Their objective is completely pragmatic, namely, to tell the government, the armed groups, the international community, and their Colombian compatriots: "Please, stop killing us." In relation to social change and this pragmatic objective mentioned above, these songs have focused both on the community as a way of helping in the processing of the loss and pain of their loved ones, and also on the government as a means of requesting protection and reparation. They have also been made for an external audience located in the urban centers of the country, which for the most part has remained uninterested in the war afflicting the rural regions of the country.

If the news did not report precisely what was happening in these isolated Afro-descendant communities, the alabaos did so by emotionally affecting the listeners through their melancholic tempo and, above all, through the powerful participation of a group that repeated in a kind of "responsorial chorus" the facts, their demands, and their pain for the dead. Saulo Enrique Mosquera, a peasant member of the Pogue singers, speaking about the composition and modification of traditional lyrics, describes that because of "the world's situation, and what has been going on in the country, we have been accommodating things so that the rest of society learns that there are people here who feel what is really going on in Colombia. And so that we don't settle for impunity". ${ }^{27}$

Reading the historical records from the 1990s to the present of massacres and targeted assassinations committed during the Colombian conflict, one is horrified by the extreme levels of impunity and nastiness present in the memory of the conflict. Nevertheless, most educated Colombians deny such conditions or validate them by saying that the paramilitaries were "a necessary evil," because otherwise the leftist guerrillas would have won the war. Through this idea they absolve the State and cynically wash their hands excusing themselves of any responsibility in the paramilitary-guerrilla conflict, despite the fact that even in large capital cities the presence of peasant families displaced by the conflict demanding alms at traffic lights is undeniable. In this context, through alabao, both the singers and the community become agents that advocate for social change at the national level; their strategies include pointing out how necropolitics intertwines with racism. As expressed in an alabao by Ana Oneida Orejuela Barco of the Pogue singers:

27 Voces de resistencia: Cantadoras de Pogue (Cali: ICESI University, 2016-2017). 


\author{
Virgin of the Candelaria, Patroness of Bojayá \\ Here we come to sing because we want peace \\ What happened in Bojayá \\ That was already warned \\ They informed the Government \\ And it didn't pay attention \\ Just because we are Black \\ They treat us that way \\ They declare war on us \\ To get us out of our land..$^{28}$
}

In another alabao by Cira María Pino Palacios, it is said verbatim: "And go tell the media/ not to erase memory," which indicates the desire to question the official and hegemonic representation of events in the public sphere. We can say that in these alabaos the community performatively expresses its particular requests, contradicting the role of passive subject of state aid, international support or academic studies. On this matter, it is quite telling that the arrival of various international organizations, academics, and state agencies into the area where the massacre occurred was ironically called the "Vests Fair" by the local community. ${ }^{29}$ This allows us to see the great skepticism of the village regarding the people who would listen to their claims and demands. It is clear that villagers believed these organizations were there to serve their own interests, but not those of the community. It also indirectly refers to the safari-style pocket vests that Americans and Europeans often use when doing field work in the so-called Third World and which, for the locals, seems more like a uniform.

To avoid the cultural domination and subordination of the slave culture that is at the core of these new alabaos, we can observe that the bond established by the community with the saints, the Virgin Mary and Jesus is no longer sufficient. In other words, the bond established by the community in traditional alabaos is not enough to rehumanize a community and to restore its sense of identity, especially when, as Longoni affirms, "the human form has been lost $" .{ }^{30}$ Nor can this link restore the local people's connection to a territory that is continually threatened not only by the guerrillas and paramilitaries, but also by drug traffickers related in varying degrees with the former and spurred on by the economic interests of national and multinational companies. Expressed in a different way, despite mentioning the saints, Jesus and the Virgin, these new alabaos focus on the pragmatic goals of stopping the violence, obtaining reparation, and reclaiming the dead. They do not center primarily on moral or religious ideologies, such as the afterlife or forgiveness.

It may be difficult to understand how a group of women can be allowed to sing such serious demands without being attacked by militaristic actors in the Colombian conflict, given the

28 Vergara, "Suffering While Black: Resistance amid Deracination.", 75-76.

29 Sánchez(coord.) et al, Bojayá: la guerra sin límites: Historical Memory Group Report on Bojayá.

30 Longoni, "Perder la forma humana." 
background of widespread threats and frequent killings of civilians that have occurred during the period from the 1990s to the present. In this regard, Botero and Vergara sustain that the Pogue singers are able to use alabaos to denounce evil because they are "mainly organized by women" and, as such, "they seem to present no threat to the armed groups". ${ }^{31}$ For this reason, we believe that it is the strategic use of the prevailing idea of the feminine as the submissive that allows them to speak out. In the words of bell hooks, the alabaos build these women's (and men's) "right as a subject in resistance to defining reality". ${ }^{32}$

\section{The Politics of Performing}

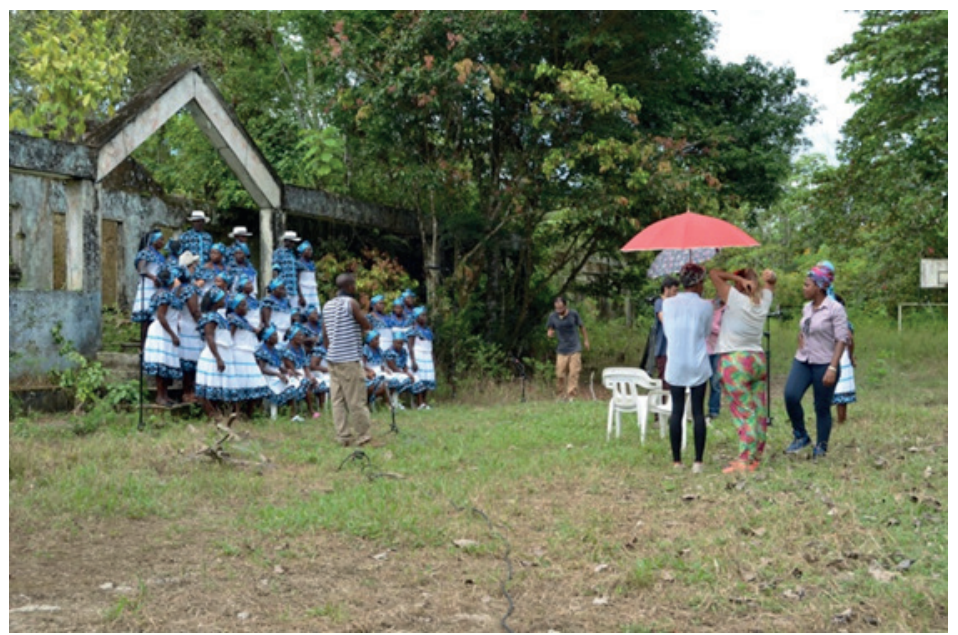

The Pogue Singers during the documentary Voces de Resistencia (ICESI)

It is significant to note that the participation of women from an early age in community rites, especially in the performance of music, has given them continuous training in lyrical structure and musical patterns. This has allowed them to respond actively and publicly to the type of traumatic events that we have been describing. We can relate this fact to the "autonomous" trait that Botero and Vergara identify in the alabaos of the Pogue singers, since their new alabaos are performed, not during the funeral rites of specific individuals, but in a separate and parallel cultural production for the purpose of commemorating, in a regional ceremony, the 2002 massacre every May 2. They also sing at other community events in the Atrato area related to denouncing threats and attacks on civilians.

The Pogue singers have themselves become an art form, as the singers themselves claim. In an interview, Cira María Pino Palacios explained that singing was born with her, but it was

31 Botero and Vergara, "Cantando el territorio", 8.

32 bell hooks, Teaching to Transgress (New York: Routledge, 1994), 65. 
when the massacres began to take place, and the people in her group began to compose their own lyrics, that this activity became an art. ${ }^{33}$ Alabaos bring together art and life, the individual and the community, the spirits of the dead and the living. This can be seen when analyzing the way in which they are performed as Valencia Caizamo affirms: "The way in which alabaos are performed is very open, and not defined by a specific tempo. It depends on the passion and inspiration of the performer". ${ }^{34}$ We could say that in terms of embodiment practices and what in the West we would call "theatricality", whenever the alabao is performed the singers balance their bodies to describe the phrasing of the melody and the musical rhythm since the gestures of the performer play a very important role and the executors or facilitators never stand still.

Another interesting aspect of these new alabaos is the reference to the deficient and incomplete documentation of the victims of the conflict by the government. "If the victims register, by protocol, did not include the dead children in their mother's bodies, the 'alabaoras' reconstructed their names and included them in the 'alabaos.' If by a mistake someone was left outside the register of victims, the 'alabaos' amended this error" ${ }^{35}$ In this sense, we could say that the Pogue singers, in the absence of the bodies, go from a spiritual community context to a public stage beyond the community to affirm the names of the beings that have been made to disappear. It is an act of open opposition to the necropolitics of both the armed groups and the Colombian State, and in particular the official government reports on the Bojayá massacre, which are always fragmentary. In this sense, it is meaningful what Bharucha affirms about the recreation of traditions and myths of the past, which can help us to see the present not so much because these myths are being revived in what could be an "eternal present", but rather because this new representation of myths acquires new meanings (in some way altered) in a simulation of what has already happened. "It is only by puncturing the counterfeit of similitude that the reality of dissimilitude becomes visible". ${ }^{36}$ To some extent the new alabaos are genuine connections with the community's past, as well as a demand for the right to a dignified life in a context of extreme dehumanization where both the dead and the living are in an indeterminate state or limbo.

Here we would like to note that in many traditional cultures around the world, art is understood as part of life and, therefore, cultural productions are not called "art", as is the case with the alabaos. In fact, the field of performance studies, as interdisciplinary and open as it may seem, emerged within a Western cultural background rooted in the Renaissance, which prejudiced the individual artist over any collective conception of cultural life. It is our opinion that even if cultural performative acts around the globe have been legitimized in our day as

33 Voces de resistencia: Cantadoras de Pogue.

34 Valencia Cáizamo, "Alabaos y chigualos-gualíes del Chocó traídos al escenario recitalístico del cantante lírico", 21.

35 Botero and Vergara, "Cantando el territorio.", 13.

36 Bharucha, Performance and Terror, 13. 
worthy of analysis on an equal footing with Western "art," we theater researchers should still be aware that the idea of the individual Western artist as superior is still very influential in our field. We consider alabaos to be a form of empowerment that has been created against the hegemonic culture and politics of Colombia and Latin America. It is the reason why the Pogue singers call what they do "art" as a way of situating their interpretation within the dominant value system and to communicate with the armed groups, the State and their many compatriots who deliberately overlook the reality of what is happening in their country outside the main urban centers.

As we mentioned initially, in order to represent the victims of the conflict, the Pogue singers were invited by President Juan Manuel Santos to interpret their alabaos in the official ceremony of the peace agreement that took place in Cartagena de Indias on September 26, 2016. This produced more than one paradox. In this televised ceremony, the Bojayá massacre was officially narrated as if it had a closure, a happy ending. This is as if the massacre was an item from the past that had magically become a symbol of national hope. Mabel Lara, a young black television presenter, introduced the group as follows: "These women used to wear black to sing to the pain of war; now they are singing to the hope of peace". However, as has been experienced by these singers, sadness and mistrust cannot simply end for people who have suffered such traumatic events for so long. In this sense, this public act was not very different from the old dynamic of leaving Afro-descendant communities out of national discourse.

Analyzing the ceremony, we can say that the alabao singers resisted this official narrative. Dressed in white instead of their traditional dress (the staging or mise en scène by the Colombian state required that they be in white as the president and most of the official guests), they sang an alabao that asked the Virgin Mary for peace, congratulated the president and praised the FARC for surrendering their weapons, but also, they recalled how seriously their community had been hurt. In their songs they affirmed that it was imperative that there be justice and reparation, and they asked the armed groups, including the FARC, not to repeat these violent acts. ${ }^{37}$ Coming to the end of their acting, when their song of lament began to increase in tempo, the singers accentuated that the government's responsibility did not end with the peace agreement. At that moment, instead of continuing on stage facing the public, they turned to look at the president, pointed at him and chanted: "Listen, Mr. President, come near us / and tell us / what will happen with the other armed groups". With this gesture, they were not only asking the president to get closer to their reality, but were also referring to the fact that as of 2016 the communities along the Atrato River continued to be threatened by new paramilitary groups and the guerrillas of the National Liberation Army (ELN), a group different from the FARC. The progressive political magazine La Silla Vacia published this headline about the event: "The Alabao Singers Scolded the Government and the FARC".

37 Ibid. 
Despite the irrationality of extending the bloodshed resulting from more than half a century of armed conflict in the countryside (especially considering the fact that none of the armed actors had an objective chance of winning the war), as we announced at the beginning of this essay, $50.2 \%$ of the Colombian population voted "no" to ratification of the peace agreement in the October referendum of 2016. In stark opposition to the national result, in Chocó and most other regions with large Afro-descendant and indigenous populations, the majority voted in favor of the peace process, including an overwhelming 96\% in the Bojayá area. In reply to the country's negative vote, the Pogue singers sang:

Those who didn't know and voted no
God bless their memory
That they might better reflect....
To Santos and Uribe Vélez,
Sit down to rethink.
This dialogue of peace
Should become reality.

Let us observe how Pogue's singers emphasize in their composition the ignorance of their compatriots about the reality of their country. Following the strategy of traditional alabaos, they allude to the gospel, particularly Luke 23:34: "Father, forgive them, for they know not what they do." However, instead of leaving the issue in the hands of God, as a traditional alabao would, they focus on telling the two most influential politicians in the country to negotiate their disagreements. At the beginning of this essay, we said that the Pogue singers, while supporting the peace negotiations, embodied the awareness that the process of public mourning (as well as justice and reparation) was far from conflict-free. Current events in Colombia lend credence to their misgivings.

In 2018, at the end of the presidency of Juan Manuel Santos, Iván Duque, a close ally of Álvaro Uribe, was elected president of Colombia. As president, Duque chose history professor Rubén Darío Acevedo as the new director of the National Center for Historical Memory. In 2019 Acevedo was the government representative at the official ceremony held in Bojayá to return the remains of the victims of the 2002 massacre to their families. At the event he insisted, to the astonishment of those present, that "there were only two protagonists of the

38 As has been established by the Human Rights Watch report on Colombia, the far-right Álvaro Uribe-Vélez (Colombian president before Juan Manuel Santos), has adamantly led political opposition to any peace agreement with the leftist guerrillas, advocating instead for their extermination, but as president he was quick to reach a demobilization agreement with the paramilitary that did not actually end these organizations or hold them accountable for their crimes (see the 2005 Human Rights Watch report on Colombia). 
massacre: the guerrillas and the paramilitary". ${ }^{39}$ The response of Leyner Palacios Asprilla, representative of the Inter-Ethnic Truth Commission for the Pacific Region highlights the difficulty Afro-descendant and other isolated communities will have in trying to bring about change. Palacios Asprilla emphasized that:

there were three actors in the massacre: the FARC; the paramilitary, who used us as a human shield; but also the state authorities for neglecting their duty to restrain the attack. ... I hope the next encounter with the state will begin to create an environment of trust, but how can trust be created when violence and fear have returned to Bojayá? Today we are with the dead, but also with the fear of what is going on. Today the paramilitary and the ELN guerrillas are near many communities... Today the state forces continue being as dismissive as in 2002, and then they say they knew nothing about it. We are tired of picking up bodies. ${ }^{40}$

In this way, we can see not only how the wounds of war remain open in Colombia but also how the conditions produced by the current government have created conditions which hinder their closure.

\section{By Way of Conclusion}
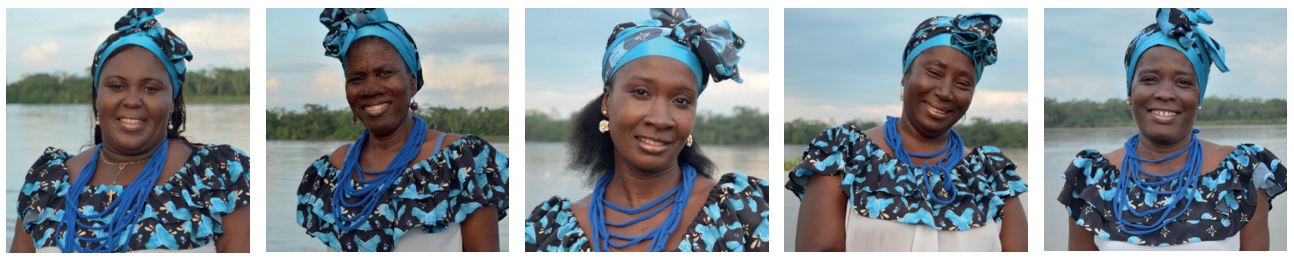

Esmila Díaz Asprilla, Luz Mary Mosquera Orejuela, Maricel Mosquera Pino, Máxima Asprilla Palomeque, Rosmira Palacios Pino,
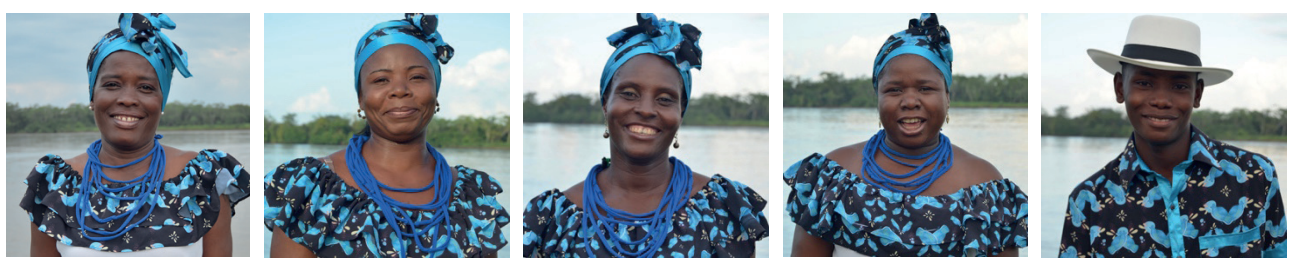

Ana Oneida Orejuela Barco, Yesenia Lizcano Rentería, Helia del Carmen Mosquera, Marledys Palacios Asprilla, Jhon Mario Mosquera Orejuela,

39 The appointment of Rubén Darío Acevedo has been considered one of the most notable gaffes of the Iván Duque government because Acevedo, like the vast majority of Colombian right-wing elites, is a denier (negacionista) of the existence of an armed conflict in the country. The political consequence of this statement is that the State is not responsible for human rights violations, nor does it have obligations to the victims regarding truth, justice, reparation and non-repetition. This appointment in one of the most sensitive organizations dealing with the conflict has put at risk the entire documentary archive and the testimonies of the massacres that occurred in the last 50 years in Colombia. Due to this, Colombia lost its membership in 2019 to the International Coalition of Sites of Conscience, an international network that brings together 275 entities from 65 different countries. Uno a Uno: Bojayá-memoria atrasada.

40 Uno a Uno: Bojayá-memoria atrasada. 

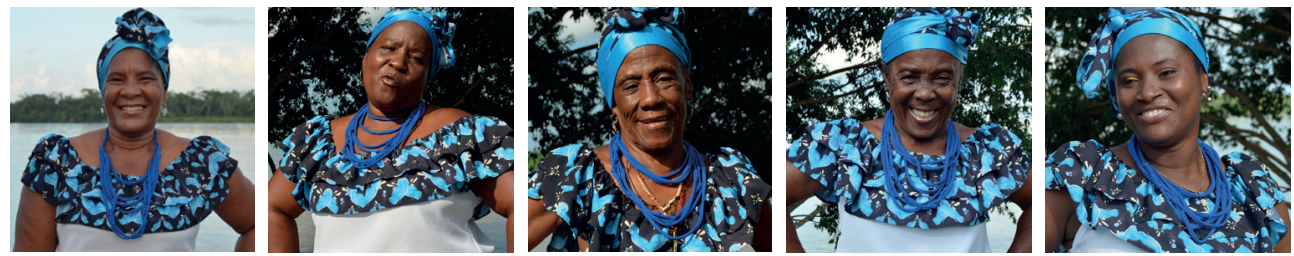

Ereiza Palomeque Palacios, Luz Marina Cañola de Palacios, Rosa Isabel Rentería Cuesta, Zenaida Mosquera Palacios, Luz Mary Mosquera Orejuela,
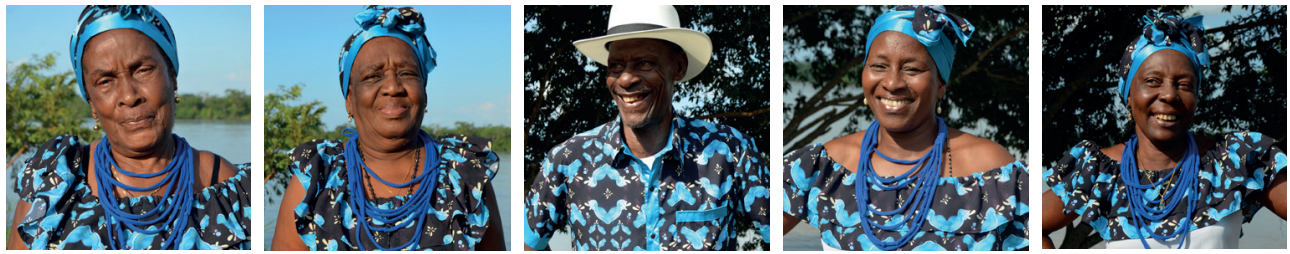

Paula Correa Cuesta, Eulogia Asprilla de Palacios, Saulo Enrique Mosquera, Rufina Chavarra García, Juana Francisca Rivas Cuesta,
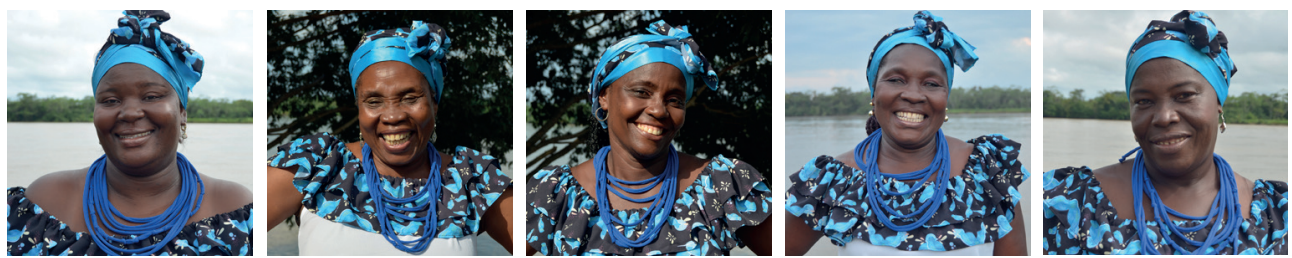

Idalis Díaz Asprilla, Cira María Pino Palacios, Floriana Mosquera Rivas, Marcelina Pino Mosquera,Nilda Palacios Pacheco,
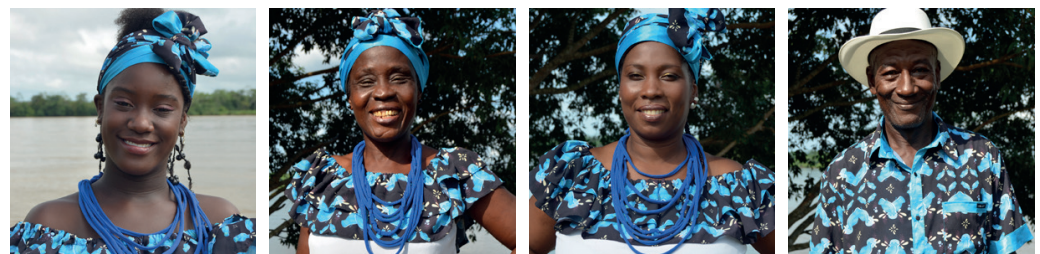

Yenny Andrea Mosquera Mosquera, Eugenia Palacios Palacios, Emilia Hinestroza Pino and Esaú Palacios Hinestroza.

The Pogue singers work within the ancestral tradition of the alabao of slave origins to repair deep fractures in community life and memory caused by the impossibility of maintaining ancestral funeral rites, such as the alabao mourning songs. From the local collective traditions, they project their claims beyond the community and on the national (and international) scene, becoming a symbol of all the victims of the Colombian armed conflict. In doing so, they attempt to repair profound gaps in collective memory, particularly with regard to the experience of women. This practice is based mainly on the perspectives of female subjects who, through 
performative practices, actively mobilize the memory of the armed conflict towards collective experiences that have been - and still are - silenced in the media and official discourse.

This performative cultural practice does not take an ideological side to the conflict, nor does it assume a nationalist, moralistic or triumphal perspective of it. On the contrary, this cultural practice is based on absent and injured bodies and goes against the tide of a society that continues to relegate marginalized communities to limbo, a society that continues to value the authoritarian war strategies of previous governments, as demonstrated by the recent election (2018) of Iván Duque as president. According to the report of the Institute of Studies for Development and Peace, ${ }^{41}$ in the first two years of the Duque government, 573 social leaders and human rights defenders were assassinated in Colombia.

In this article we highlight an artistic practice that cannot be detached from political practice, particularly in countries where widespread terror informs daily life. In this context, this cultural practice of the alabaos activates historical memory and presents it as a place of tension and reinvention of politics from the point of view of the unarmed.

Peer-review: Externally peer-reviewed.

Conflict of Interest: The authors have no conflict of interest to declare.

Grant Support: The authors declared that this study has received no financial support.

Hakem Değerlendirmesi: Dış bağımsız.

Çıkar Çatışması: Yazarlar çıkar çatışması bildirmemiştir.

Finansal Destek: Yazarlar bu çalışma için finansal destek almadığını beyan etmiştir.

\section{BIBLIOGRAPHY / KAYNAKÇA}

Agamben, Giorgio. Homo Sacer: El poder soberano y la nuda vida. Valencia: Pre-textos, 1998.

Arango-Melo, Ana. Velo que bonito: Prácticas y saberes sonoro-corporales de la primera infancia en la población afro-chocoana. Bogotá D.C.: Opciones Gráficas Editores, 2014.

Bharucha, Rustom. Performance and Terror. New York: Routledge, 2014.

Botero, Jerónimo, and Aurora Vergara. "Cantando el territorio". Paper presented at the annual meeting for the Latin American Studies Association Congress, Barcelona, May 23, 2018.

De la Torre, Gonzalo (compilator and editor). Alabaos. Misioneros Claretianos Colombia. Quibdó: 2005. hooks, bell. Teaching to Transgress. New York: Routledge, 1994.

INDEPAZ. "Informe Especial: Asesinato de lideres sociales”. July 15, 2020. http://www.indepaz.org.co/wpcontent/uploads/2020/07/Informe-Especial-Asesinato-lideres-sociales-Nov2016-Jul2020-Indepaz.pdf

41 INDEPAZ, «Informe Especial: Asesinato de lideres sociales», accessed July 15, 2020, http://www.indepaz.org. co/wp-content/uploads/2020/07/Informe-Especial-Asesinato-lideres-sociales-Nov2016-Jul2020-Indepaz.pdf. 
Longoni, Ana. "Perder la forma humana". Cartografias críticas I. Edited by Ileana Diéguez, Paola Marín, and Gastón Alzate. Los Angeles: Karpa, 2018. www.calstatela.edu/al/karpa/longoni.

Maya, Adriana. "Africa: Legados espirituales en La Nueva Granada, siglo XVII", Historia Crítica 12/1 (1996): 29-41.

Mbembe, Achille. Necropolitics. Durham, NC: Duke University Press, 2019.

Quiceno, Natalia; Ochoa Sierra, María and Marcela Villamizar, Adriana. "La política del canto y el poder de las alabaoras de Pogue (Bojayá, Chocó)”, Estudios Políticos 51 (2017), 175-195.

Rinaldi, Ray Mark. "A Peace Monument in Colombia Is Caught in a Crossfire". New York Times, October 23, 2019.

Sánchez, Gonzalo (coord.), et al. Bojayá: la guerra sin límites. Historical Memory Group Report on Bojayá. Bogotá: CNRR — Grupo de Memoria Histórica, Ediciones Semana, 2010.

Schechner, Richard. Performance Studies: An Introduction. New York: Routledge, 2002.

Stachelhaus, Heiner. Joseph Beuys. Translated by Joan Godo Costa. Barcelona: Parsifal Ediciones, 1990.

Uno a Uno: Bojayá-memoria atrasada. Diocese of Quibdó and PAZIPAZ, producers 019. www.youtube. $\mathrm{com} /$ watch?v=KmzOJ1y-S4g.

Valencia Cáizamo, Nelly. "Alabaos y chigualos-gualíes del Chocó traídos al escenario recitalístico del cantante lírico." Master's thesis, EAFIT University, Medellín, 2015. https://repository.eafit.edu.co/ bitstream/handle/10784/8048/Nelly_ValenciaCaizamo_2015.pdf?sequence=2\&isAllowed=y.

Vergara, Aurora. "Suffering While Black: Resistance amid Deracination." In Afrodescendant Resistance to Deracination in Colombia. London: Palgrave McMillan, 2018, 69-80.

Voces de resistencia: Cantadoras de Pogue. ICESI University, Cali, producer. 2016-2017. 